\title{
Submandibular Gland Adenocarcinoma of Intercalated Duct Origin in Smgb-Tag Mice
}

\author{
Irving Dardick, James Ho, Michelle Paulus, Pamela L. Mellon, and Lily Mirels \\ Department of Pathology (ID), University of Toronto, and Department of Pathology (JH), Princess Margaret Hospital, \\ Toronto, Canada; and Department of Reproductive Medicine (MP, PLM), University of California at San Diego, La \\ Jolla, and Department of Molecular and Cell Biology (LM), University of California, Berkeley, California
}

SUMMARY: A line of transgenic mice that develops submandibular gland adenocarcinoma of intercalated duct origin was established. In these mice, the oncogene SV40 T antigen (Tag) is expressed from the neonatal submandibular gland secretory protein b (Smgb) gene promoter. This hybrid gene directs expression of the oncoprotein to neonatal submandibular gland proacinar and terminal tubule cells and to intercalated ducts of the adult gland. Transgene expression resulted in duct luminal cell hyperplasia as early as 20 to 30 days postnatally, which progressed to dysplasia by 3 to 4 months of age. Marked dysplasia and in situ carcinoma were evident at 4 to 6 months of age. All histologic changes were more pronounced in males. Submandibular gland adenocarcinoma developed stochastically in more than half of the adult male mice by 12 months of age (average age: 10.8 months, range: 6 to 13.5 months). Tag expression persisted in in situ carcinoma and all tumors. Using a combination of immunocytochemical and ultrastructural criteria, submandibular gland dysplasia and tumors were found to originate from intercalated ducts. The dysplastic ducts and adenocarcinoma in Smgb-Tag mice were morphologically similar to previously reported Tag-induced dysplasias of striated ducts and granular convoluted tubules and a Tag-induced adenocarcinoma of striated duct origin. These findings demonstrate that salivary gland dysplasias and tumors of similar histologic appearance can arise from distinct differentiated cell types. Analysis of the molecular changes accompanying tumor formation in Smgb-Tag mice could increase knowledge of human salivary gland tumorigenesis. (Lab Invest 2000, 80:1657-1670).

$$
T
$$
he etiology and pathogenesis of human salivary gland tumors remain unresolved. Radiation to the head and neck is one potential cause. A number of studies found an association between external radiation therapy to the head and neck and subsequent development of salivary gland malignancies, especially in children (Maxon et al, 1981; Modan et al, 1974; Palmer et al, 1980; Spitz et al, 1984). A similar association was observed in survivors of the atomic bombing of Japan (Belsky et al, 1975).

Viral induction is also a suspected cause of human salivary gland tumors. Although polyoma virusinduced salivary gland tumors have been demonstrated in mice (Eddy, 1969; Dawe, 1979), evidence of viral induction is circumstantial in humans. Both genetic predilection and Epstein-Barr virus are implicated in the high incidence of undifferentiated carcinoma of lymphoepithelioma type observed in the major salivary glands of Greenland Eskimos and South Chinese (Borg et al, 1993; Hamilton-Dutoit et al, 1991). Additionally, a high proportion of lymphoepitheliomalike carcinoma of salivary gland cases in both Taiwan and Japan are positive for Epstein-Barr virus-encoded

Received June 19, 2000.

This work was supported by a grant from the National Institutes of Health (NIH Grant DE09428).

Address reprint requests to: Dr. Lily Mirels, Department of Molecular and Cell Biology, 401 Barker Hall \#3204, University of California, Berkeley, California94720-3204.E-mail: lmirels@uclink4.berkeley.edu
RNA by in situ hybridization (Kuo and Hsueh, 1997; Nagao et al, 1996; Sheen et al, 1997; Wen et al, 1997).

In rodents, there is a long interval between chemical carcinogen, viral, or radiation induction and tumor presentation. Nothing is known about this intermediate, probably multistep, phase of human salivary gland tumors. Transgenic mice can provide model systems for the study of the molecular basis for salivary gland tumor development (Breuer, 1991; Furth et al, 1998). Salivary gland hyperplasia and tumors have been observed in transgenic mice containing the mouse mammary tumor virus long terminal repeat (MMTV LTR) driving expression of activated Ras or Ras plus Myc (Sinn et al, 1987), Wnt-1 (Tsukamoto et al, 1988), Wnt-3 (Jhappan et al, 1992), Fgf-8 (DaphnaIken et al, 1998), Neu (Lucchini et al, 1992; Muller et al, 1988) or SV40 T antigen (Tag) (Choi et al, 1987; Ewald et al, 1996; Furth et al, 1998) genes. The gland specificity of pathologic changes is variable between these models. MMTV-v-Ha-Ras mice exhibited only parotid gland abnormalities (Dardick et al, 1992), whereas in MMTV-Tag mice, submandibular gland dysplasia of striated duct was pronounced and parotid involvement was minor (Ewald et al, 1996; Furth et al, 1998). Dysplastic changes developed in submandibular, sublingual, and parotid glands of MMTVWnt 3 mice (Jhappan et al, 1992). These findings demonstrate that the MMTV LTR is potentially active in all of the major salivary glands, possibly in multiple cell types. 
A similar strategy employing transgenic mice can be used to examine the onset of dysplasia and tumorigenesis in specific salivary cells. A transgene containing the regulatory region of the mouse epidermal growth factor (EGF) gene upstream of Tag directed Tag expression to submandibular gland granular duct cells, the normal site of EGF expression. Tag expression in this model resulted in progressive ductal hyperplasia and dysplasia of granular duct cells, but no tumors developed during the observation period (Pascall et al, 1994). Adenocarcinoma, probably of granular duct origin, resulted from fortuitous submandibular gland Ras expression in transgenic mice containing potential regulatory sequences from the human prostate-specific antigen gene driving expression of the Ha-RasT24 oncogene (Schaffner et al, 1995).

We report the generation and analysis of a transgenic mouse line that develops submandibular gland adenocarcinoma of intercalated duct origin. These mice contain a transgene in which Tag expression is targeted to intercalated ducts by regulatory sequences derived from the rat submandibular gland secretory protein b (Smgb) salivary protein gene (Gupta et al, 2000). Smgb is normally expressed in neonatal submandibular gland proacinar cells, and in a subset of intercalated duct cells of the adult gland (Ball et al, 1988; Mirels et al, 1998; Moreira et al, 1990). The Smgb-Tag transgene is expressed in these cells, but also in some neonatal submandibular gland secretory terminal tubule cells, and in the majority of intercalated duct cells. Tag expression in the intercalated ducts results in progressive hyperplasia, dysplasia, and adenocarcinoma.

\section{Results}

\section{Production of Smgb-Tag Transgenic Mice}

Smgb is normally expressed in the proacinar cells of the immature rat submandibular gland and in a subset of intercalated duct cells in the adult gland. To target Tag expression to these cells, a construct containing potential transcriptional regulatory sequences from the Smgb genomic clone $\lambda 13$ (Gupta et al, 2000) upstream of the Tag coding region was prepared (Fig. 1A). The Smgb-Tag construct included $10.5 \mathrm{~kb}$ of $5^{\prime}$ flanking DNA, the transcription start site, and $30 \mathrm{bp}$ derived from the first exon of Smgb. This 13.5-kb construct was used to generate transgenic mice by standard methods. Five transgenic lines, Smgb-Tag 8, 22, 41, 43, and 49, were obtained.

Total RNA from submandibular, sublingual, and parotid glands of a 3-month-old heterozygous adult from each line and RNA from submandibularsublingual complexes of 2- to 4-day-old pups was analyzed for the presence of Tag transcripts. No Tag transcripts were detected by Northern blot analysis (data not shown), but evidence of low levels of Tag expression in neonatal and adult transgenic salivary glands was obtained by RT-PCR (Fig. 1B). A 296-bp band indicating Tag expression was seen in adult submandibular gland RNA from lines 8, 41, and 49 and from submandibular-sublingual complexes of neonates of all four lines tested $(8,22,43$, and 49$)$.

\section{Smgb-Tag Mice Develop Submandibular Gland Tumors}

Transgenic mice of lines 8, 22, 41, 43, and 49 were observed for evidence of submandibular gland tumor formation. Male and female heterozygous mice of lines 41 and 49, which had the highest transgene copy number, consistently succumbed to pancreatic tumors between 3 and 4 months of age without gross evidence of salivary gland pathology. The remaining three lines were made homozygous and observed over a period of one year. During this time, submandibular tumors developed in three of seven male Smgb-Tag line 8 mice. No tumors were observed in lines 22 or 43 , consistent with the lower or undetectable levels of Tag expression in the adult submandibular glands of these mice. Only line 8 was studied further; mice referred to as Smgb-Tag mice are all of this line.

Twenty-nine homozygous Smgb-Tag male mice were observed over a period of 13 months (Table 1). Within this group, 18 mice (62.1\%) developed submandibular gland tumors, some bilaterally. Eight of the remaining mice $(27.6 \%)$ were euthanized because of illness, which was probably related to ectopic Tag expression, without gross evidence of salivary gland tumors. Only 3 of the 29 male Smgb-Tag mice (10.3\%) seemed healthy and were free of palpable salivary gland tumors at 14 months of age. Female Smgb-Tag mice developed tumors infrequently. However, tumors derived from females and males were histologically similar.

\section{Submandibular Tumors in Adult Transgenic Mice}

In Smgb-Tag mice, submandibular gland tumor patterns varied from diffuse to variably defined lobules or discrete nests within a fibrous stroma (Fig. 2A, B). Many tumors were unencapsulated and extensively infiltrated the submandibular gland (Fig. 2C), whereas others had broad expansive margins (Fig. 2D). No lymph node or distant metastases were noted. Distinct glandular structures in well- to poorly differentiated tumors indicated that these were adenocarcinomas (Fig. 2A, B). Some lesions were entirely undifferentiated, often with foci of necrosis.

Cytologically, in well- to poorly differentiated tumors, only luminal type cells seemed to differentiate. These cells varied from cuboidal or low columnar to polygonal in form with acidophilic cytoplasm and nuclei with coarsely clumped heterochromatin (Fig. 2B). Many tumor cell nuclei were hyperchromatic. Mitotic figures were numerous and often abnormal in form. In all tumors, regardless of the degree of differentiation, a majority of tumor cell nuclei were immunoreactive to a Tag antibody (Pab 101) (Fig. 2E). Similarly, immunoreactivity to a PCNA antibody (PC 10) showed that a considerable proportion of tumor cells were cycling (Fig. 2F). Tumor tissue was unla- 
A

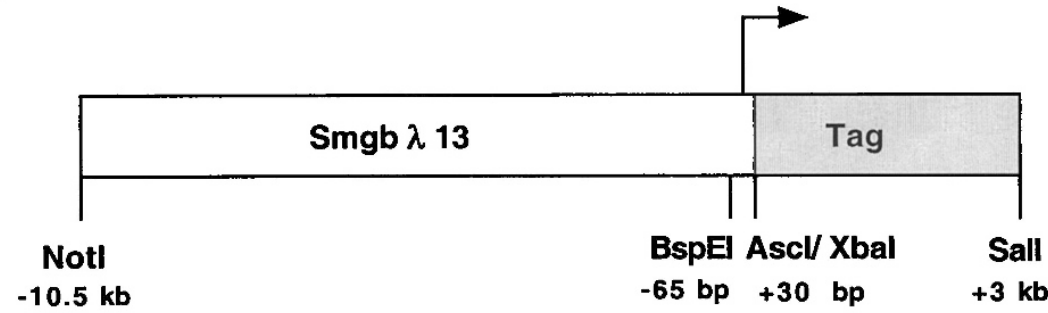

B

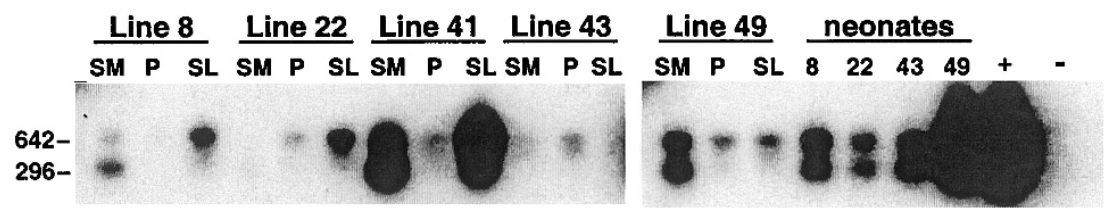

Figure 1.

Submandibular gland secretory protein b (Smgb) sequences target SV40 T antigen (Tag) expression to neonatal and adult submandibular glands. A, The Smgb-Tag transgene contains Smgb sequences from $-10.5 \mathrm{~kb}$ to +30 relative to the Smgb transcription start site (arrow) upstream of the SV40 T and t antigen genes (Tag). Principal restriction sites in the Smgb $\lambda 13-$ Tag construct are labeled. B, RT-PCR of RNA from submandibular (SM), parotid ( $P$ ), and sublingual (SL) glands from adults of Smgb-Tag mouse lines 8, 22, 41, 43, and 49 and from submandibular/sublingual complexes of neonates from lines 8, 22, 43, and 49. The 296 bp bands indicate Tag transcription, whereas the 642 bp bands are derived from genomic DNA. +, positive control; -, negative control.

Table 1. Morbidity and Submandibular Gland Tumor Formation in Male Smgb-Tag Mice ${ }^{a}$

\begin{tabular}{lrrrrrr}
\hline & \multicolumn{7}{c}{ Age range $(\mathrm{mo})$} \\
\cline { 2 - 7 } & $0-3$ & $4-5$ & $6-7$ & $8-9$ & $10-11$ & $12-13$ \\
\hline Healthy & 29 & 27 & 25 & 17 & 11 & 3 \\
SMG tumor & 0 & 0 & 2 & 6 & 3 & 7 \\
Sick/Other & 0 & 2 & 0 & 2 & 3 & 1 \\
\hline
\end{tabular}

SMG, submandibular gland.

${ }^{a}$ Twenty nine male mice were observed longitudinally over a 13-month period. Mice that developed submandibular gland tumors were otherwise asymptomatic and were sacrificed within 1 month of initial detection (average age, $10.8 \mathrm{mo}$; range 6-13.5 mo). Mice that appeared ill were euthanized immediately.

beled when the primary Tag antibody was omitted from the immunohistochemistry procedure (Fig. 2G).

Ultrastructurally, in both well- and poorly differentiated tumors, the glandular nature of the submandibular tumors was confirmed. Distinct lumens formed by tumor cells with limited apical microvilli were readily identified (Fig. 3A), with a few luminal cells containing occasional, relatively large, secretory granules (Fig. 3B). These granules were compartmentalized, with a smaller, darkly staining, round, eccentrically placed portion surrounded by paler staining, flocculentappearing material (Fig. 3B). Rarely, evidence of glandular differentiation was seen in undifferentiated carcinomas, where tumor cells were attached by elongated occludens-type (tight) junctions to form a tiny lumen mainly occupied by a few short, thickened microvilli (Fig. 3C).

\section{Duct Dysplasia and In Situ Carcinoma in Transgenic Mice}

In all adult male Smgb-Tag mice, the submandibular gland had multiple aggregates of abnormal ducts and gland-like structures (Fig. 4A). These were present in residual submandibular glands associated with tumors, in contralateral submandibular glands without tumors, and in the submandibular glands of older mice with no evidence of tumor formation. Some ducts were lined by closely associated cells with a high nuclear to cytoplasmic ratio and darkly staining nuclei (Fig. 4B). In others, the lumen was displaced or considerably reduced in size as a result of epithelial cell proliferation; mitotic figures were readily identified (Fig. 4B). Occasional submandibular glands contained relatively large foci in which many duct-like structures, now more variable in size and form, were juxtaposed 

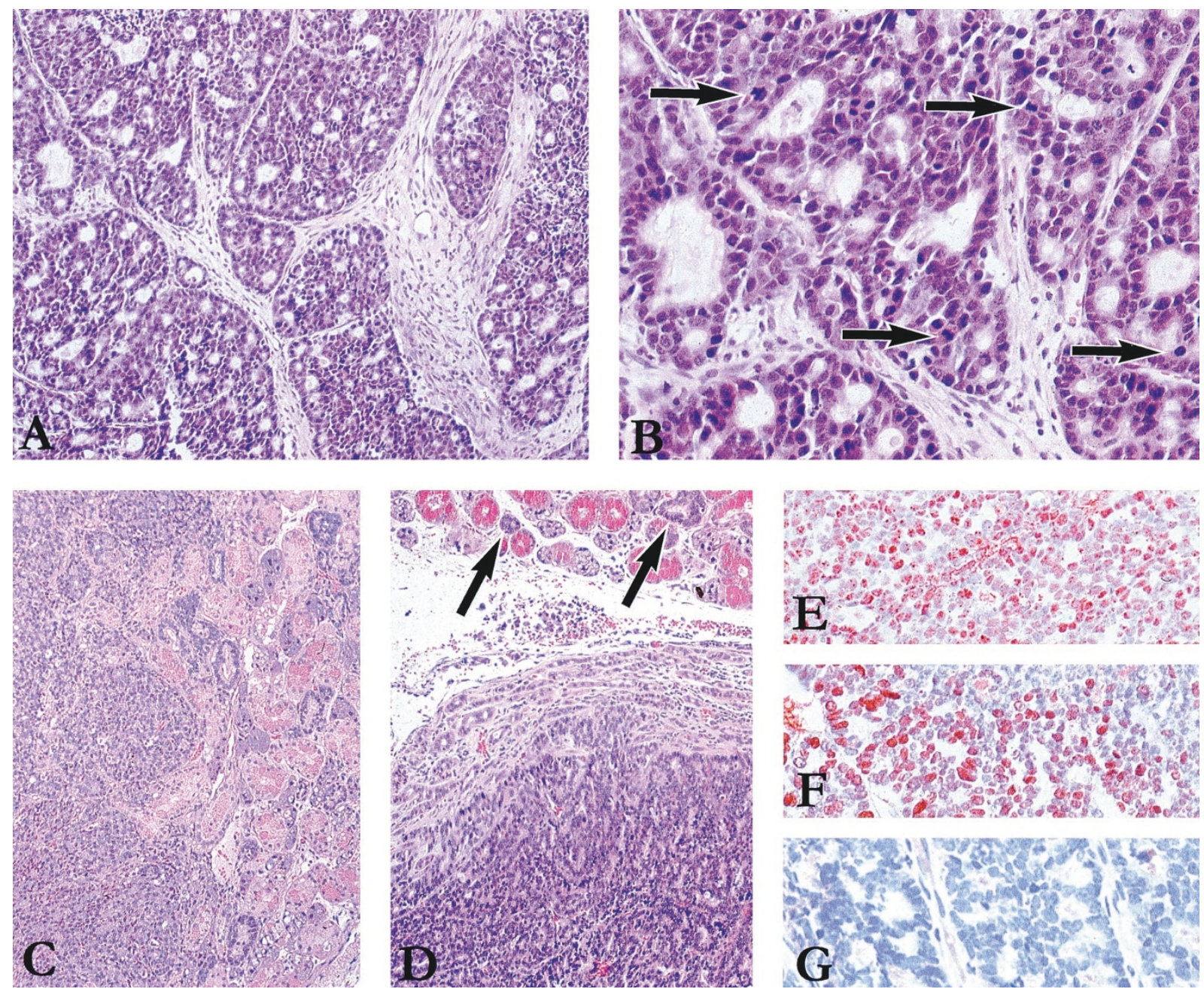

Figure 2.

Histologic features of submandibular gland tumors in male Smgb-Tag mice. A, Well-differentiated adenocarcinoma, at 9 months of age, with variably sized lobules Hematoxylin and eosin (H\&E); original magnification, $\times 100$. B, Same case as in A, with tumor cells forming round to irregularly shaped lumens. Mitotic figures are frequent (arrows). H\&E; original magnification, $\times 200$. C, Poorly differentiated adenocarcinoma (8.5-month-old mouse) extensively infiltrating submandibular gland (right). H\&E; original magnification, $\times 100$. D, Expansile well-differentiated adenocarcinoma (14 months) with a pseudocapsule caused by atrophying submandibular gland. Note the abnormal ducts (arrows) in the adjacent submandibular gland. H\&E; original magnification $\times 100$. E, Immunoreactivity for Pab 101 in a well-differentiated adenocarcinoma (8.5 months of age). The majority of tumor cell nuclei express Tag. Original magnification, $\times 200$. F, Well-differentiated adenocarcinoma (9.5 months of age). PCNA immunoreactivity shows the high proportion of tumor cells that are cycling Original magnification, $\times 200$. G, Same case as in E. Tumor tissue, with omission of Tag antibody, lacks immunoreactivity. Pab 101 immunoreactivity; original magnification $\times 200$.

(Fig. 4C). The dysplastic epithelium along with the organization of the abnormal ducts of these enlarged, fairly well-defined foci suggested in situ carcinoma. Immunoreactivity to the Pab 101 antibody showed that, at least in some abnormal ducts, a considerable number of epithelial cells expressed Tag (Fig. 4D). Many abnormal ducts had a few to many epithelial cells in the cell cycle (PCNA immunoreactive) (Fig. 4E), whereas only rare proliferating cells were seen in the rest of the submandibular gland parenchyma or in submandibular glands from CB6F1 control mice (not shown). Parotid and sublingual glands of both male and female Smgb-Tag mice were histologically indistinguishable from controls and showed no evidence of increased cell cycling. Parotid and sublingual glands were not immunoreactive for Tag, consistent with the
RT-PCR results (Fig. 1B). Salivary glands of CB6F1 control mice were also not immunoreactive to the $\mathrm{Pab}$ 101 antibody (Fig. 4F), confirming the specificity of this monoclonal antibody in mouse tissue.

\section{Time Course of Tumor Initiation and Progression}

The cell-specificity of transgene expression and the developmental onset of Tag-induced hyperplasia and dysplasia were investigated over 6 months. Immunoreactivity for parotid secretory protein (PSP), a salivary protein co-expressed with Smgb in the developing rat submandibular gland (Ball et al, 1988; Mirels et al, 1998), was used to identify proacinar and maturing acinar cells. Three days after birth, the mouse submandibular gland remained immature. In the prelimi- 

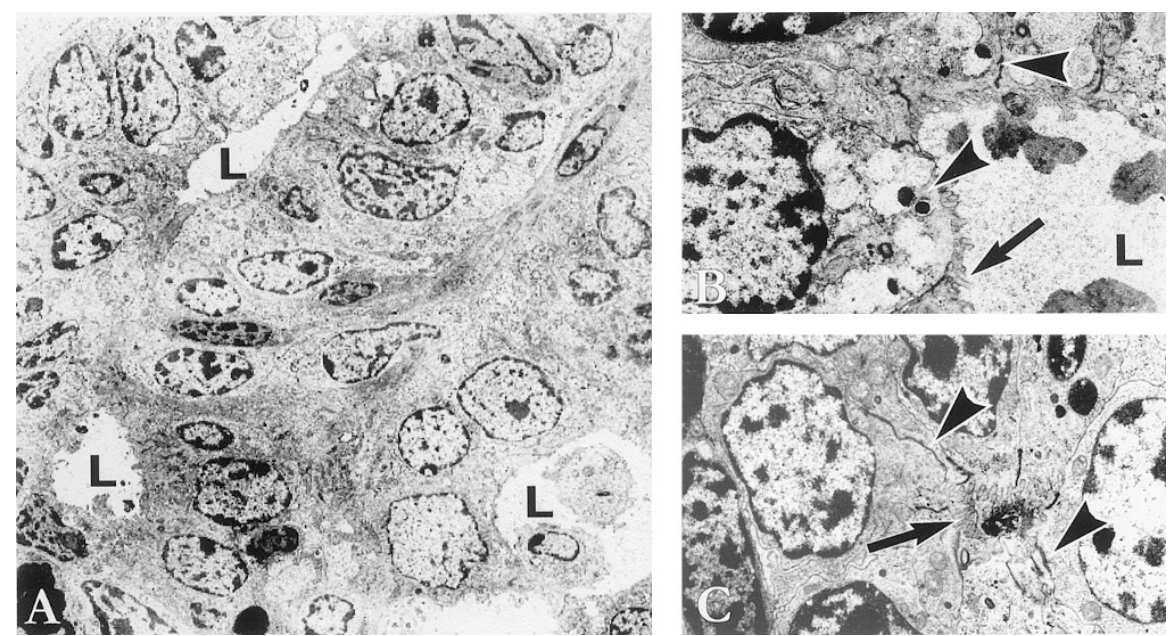

Figure 3.

Ultrastructure of submandibular gland tumors in male Smgb-Tag mice. A, Well-differentiated adenocarcinoma with cuboidal to low columnar epithelial cells forming closely associated duct-like structures with a central lumen $(L)$. Uranyl acetate and lead citrate; original magnification, $\times 1650$. B, Occasionally, in some adenocarcinomas, luminal cells with microvilli (arrow) contain groups of secretory granules, some with eccentrically placed and darkly staining cores (arrowheads). Uranyl acetate and lead citrate; original magnification, $\times 7700$. C, Putative lumens with tight junctions (arrowheads) and small numbers of packed microvilli (arrow) are noted in some poorly differentiated and undifferentiated adenocarcinomas. Uranyl acetate and lead citrate; original magnification, $\times 4600$.

nary lobules, terminal tubules branched from somewhat larger future intralobular excretory and striated ducts (Fig. 5A). At distal portions of the terminal tubules, proacinar cells, some forming early acinar-like structures, had cytoplasm with diffuse PSP immunoreactivity. Double immunolabeling with $\mathrm{PSP}$ and Tag antisera demonstrated that Tag was present in the nuclei of a high proportion of PSP-immunoreactive proacinar cells and terminal tubule cells with or without evidence of cytoplasmic PSP (Fig. 5B). Cells of the main excretory duct system were not immunoreactive for Tag. At 10 days of age, striated and intercalated ducts had increased appreciably, but the main increase in the submandibular gland parenchyma resulted from the proliferation of acinar cells (Fig. 5C). Although a considerable number of PSPimmunoreactive acinar cells expressed Tag, others did not (Fig. 5D). A number of intercalated duct cells were immunoreactive for Tag, a few of these seemed to have PSP in the apical cytoplasm (Fig. 5D). No striated or excretory duct cells were immunoreactive for PSP. By 20 days of age, many mature acini were present along with striated ducts. At this stage, granular convoluted tubules were not developed (Fig. 5E). Within the submandibular gland, there were a number of ducts that resembled intercalated ducts, but the ducts were slightly enlarged with somewhat crowded, darkly staining nuclei (Fig. 5E). Only a few widely scattered groups of cells were immunoreactive for PSP, and most of these were not immunoreactive for Tag (Fig. 5F). Most Tag-immunoreactive cells were confined to duct-like structures with many of the cells expressing Tag (Fig. 5F).

At 30 days of age, numerous small- to moderatesized ductal structures lined by moderately crowded cells with hyperchromatic nuclei persisted among the acini and granular convoluted tubules (Fig. 5G). Again, most cells in abnormal ducts continued to express Tag (Fig. 5H), with some cells proliferating at a rate much higher than surrounding acinar, striated duct, or granular convoluted tubule cells (Fig. 5I). This is considerably different from control glands, where the limited cycling cells are evenly distributed between acinar and duct cells of all types (Fig. 5J). No Tagimmunoreactive nuclei were noted in sublingual and parotid glands from 3 to 30 days of age. As an internal control, parotid acinar cells and the serous demilunes of sublingual glands were strongly immunoreactive for PSP (not shown).

From 2 to 6 months of age, abnormal ducts not only persisted in the submandibular gland, but gradually increased in prominence; by 3 months of age, some small groups of ducts with dysplastic nuclei and increased mitotic figures were present (Fig. 6A). Many nuclei in abnormal ducts were strongly immunoreactive for Tag (Fig. 6B) and were cycling (Fig. 6C). At 4 to 6 months of age (Fig. 6D), aggregates of hyperplastic/ dysplastic ducts resembled those seen in submandibular glands containing adenocarcinoma and in situ carcinoma (Fig. 4), and were the only structures expressing Tag (Fig. 6D) and maintaining a high proliferative rate.

\section{Identification of Cell-Type in Hyperplastic/Dysplastic Ducts}

Combined immunohistochemistry for muscle-specific actin (to identify myoepithelial cells) and electron microscopy localized the duct component involved in the hyperplastic/dysplastic process. In the submandibular glands of control mice, and in the submandibular glands of Smgb-Tag mice with and without tumors, the myoepithelial cells of granular convoluted tubules, intercalated ducts, and acini were immunoreactive for 

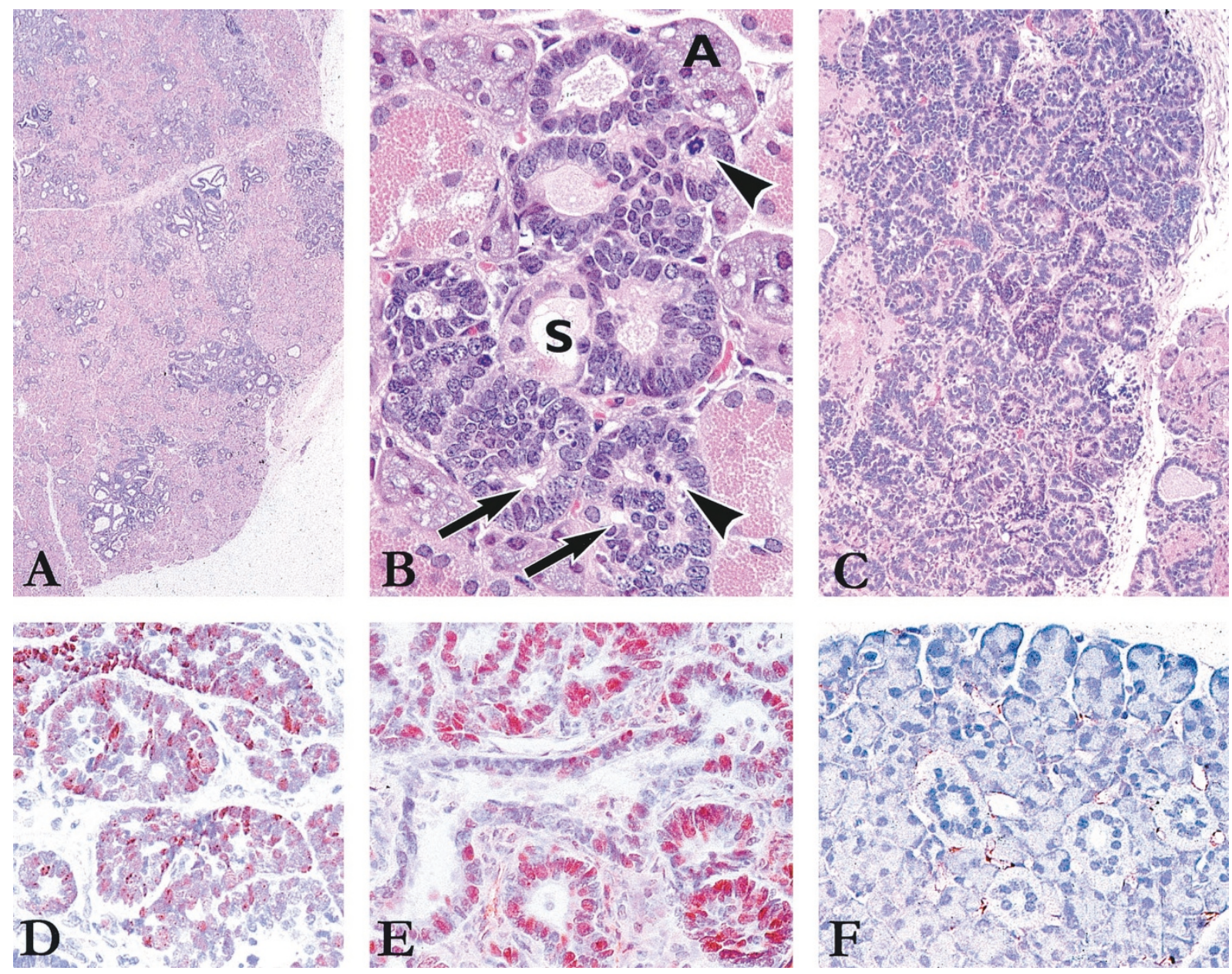

Figure 4.

Ductal pathology in Smgb-Tag mice. A, Survey micrograph from the right submandibular gland of a 13.5-month-old male with adenocarcinoma in the left submandibular gland showing the many separate abnormal aggregates of duct-like structures. H\&E; original magnification, $\times 50$. B, Same case as in A, with abnormal ducts with extensive luminal cell crowding, nuclear hyperchromasia, and mitotic activity (arrowheads). Some lumens (arrows) are displaced by epithelial cell proliferation. Note the abnormal duct at the interface with an acinus $(A)$ and the cross-section of a normal striated duct $(S)$. H\&E; original magnification, $\times 400$. C, In the right submandibular gland of a 12-month-old mouse with tumor in the left submandibular gland, an abnormal focus resembles in situ carcinoma based on the many small to moderate sized, closely associated ducts and its reasonable definition from the adjacent submandibular gland parenchyma. H\&E; origina magnification, $\times 100$. D, Tag immunoreactivity in a submandibular gland contralateral to one with tumor in a 9.5-month-old mouse. Ducts expressing Tag have a high proportion of the luminal cell nuclei strongly Tag-positive. Original magnification, $\times 125$. E, PCNA immunoreactivity of the same case as in D. Many atypical ducts have a considerable number of cycling cells. F, Parotid gland from a CB6F1 control male mouse with no Tag immunoreactivity. Original magnification, $\times 200$.

the muscle-specific actin antibody, HHF35 (Fig. 7A). Striated and excretory ducts of both control and transgenic mice were unlabeled. Many hyperplastic/ dysplastic duct profiles were almost completely, or at least partially, enclosed by flattened myoepithelial cells (Fig. 7A).

Examination of Smgb-Tag submandibular glands by electron microscopy showed that some ducts retained the general characteristics of normal intercalated ducts, with a single layer of fairly uniformly spaced luminal cells and elongated myoepithelial cells with a rich complement of cytoplasmic myofilaments at the base of luminal cells (Fig. 7B). Other ducts, still with some evidence of normal myoepithelial cells, had a marked proliferation of luminal cells and occasional mitotic figures (Fig. 7C). Ultrastructurally, no abnormalities were noted in acinar, striated duct, or granular convoluted tubule cells, indicating that the dysplastic changes were confined to cells of the intercalated ducts.

\section{Discussion}

We developed a transgenic mouse model for the study of salivary gland tumor progression by targeting the Tag oncogene to submandibular gland intercalated ducts. Tag expression resulted in progressive ductal hyperplasia, dysplasia, and carcinoma in situ in all male Smgb-Tag mice. Adenocarcinomas, which vary morphologically from well-differentiated to undifferentiated, developed stochastically in at least half of the male mice observed over a 1-year period. Pathologic changes were limited to the intercalated duct cells. This finding is based on the localization of early 
hyperplastic changes to duct segments immediately adjacent to both acini (Fig. 4B) and granular convoluted tubules (Fig. 7A), and observation of numerous dysplastic ducts bearing myoepithelial cells (Fig. 7A to C). Seromucous acini and granular convoluted tubules (both having myoepithelial cells), and striated and excretory ducts (devoid of myoepithelial cells) appear normal at all stages, although in glands of older animals acinar cells are reduced, probably due to compression by adjacent dysplastic intercalated ducts. Parotid and sublingual glands are unaffected in Smgb-Tag mice.

One of the main attributes of the Smgb-Tag model is the morphologic tracking of the premalignant process. Histologic changes in the submandibular gland of Smgb-Tag mice were preceded by detection of Tag in the nuclei of proacinar, acinar, terminal tubule, and intercalated duct cells at 3 and 10 days of age. Although hematoxylin and eosin stained sections from submandibular glands of 20 day old Smgb-Tag mice were relatively normal, Tag immunoreactivity indicated that some intercalated ducts were slightly enlarged with initial signs of luminal cell crowding at this age. At 30 days of age, enlargement and luminal cell crowding of some intercalated ducts were readily apparent. Hyperplastic intercalated ducts continued to synthesize Tag, and their luminal cells cycled at a rate much higher than in submandibular glands from agematched controls. From 1 to 6 months of age, hyperplastic modifications of intercalated ducts gradually increased and dysplastic changes in the form of epithelial cell crowding and multilayering, hyperchromatic nuclei, increased mitoses, and variable dilation and proliferation of ducts became more apparent. At 8 to 12 months of age, these preneoplastic changes were extensive in submandibular glands from transgenic mice with or without tumors. In some cases, the changes were accompanied by additional foci with histologic features of carcinoma in situ.

During normal rat and mouse submandibular gland development, proacinar cell maturation to acinar cells is largely complete by the third postnatal week. Terminal tubule cells disappear from the gland between the third and fourth postnatal week. Morphologic and TUNEL studies indicate that some terminal tubule cells contribute to the intercalated ducts, whereas others are lost via apoptosis (Gresik and MacRae, 1975; Hecht et al, 2000; Srinivasan and Chang, 1979). In Smgb-Tag mice, acinar cell maturation, as measured by morphologic appearance and loss of PSP expression, proceeded normally despite the presence of Tag in many proacinar cells. The absence of Tag in PSP-negative acinar cells suggests that the transgene is, like endogenous PSP, regulated in a developmentally appropriate manner in these cells. Similarly, terminal tubule cells were lost between postnatal days 20 and 30 in Smgb-Tag glands, as expected. However, the initial suggestions of pathologic change, in the form of epithelial cell crowding and hyperchromatic nuclei of intercalated duct cells, were evident by 20 to 30 days in Smgb-Tag submandibular glands. Tag expression seems to have a greater and more perma- nent effect on the intercalated duct cells, a mature cell type, than on the transient and rapidly dividing proacinar and terminal tubule cells.

Submandibular glands of male Smgb-Tag mice undergo more extensive ductal dysplasia and develop tumors more frequently than submandibular glands of females. Ductal alterations are more apparent in male than female Smgb-Tag mice by 30 days of age (not shown). This could result from higher levels of transgene expression in males and/or from greater sensitivity of male than female intercalated duct cells to the effects of Tag. Because of the small proportion of Tag-expressing cells in the 20- and 30-day submandibular glands and the low overall number of Tag transcripts in these glands, we did not attempt to compare levels of Tag expression in young male versus female Smgb-Tag mice. Smgb itself is expressed at similar levels in male and female rat salivary glands. Thus, if Tag transcript levels are higher in Smgb-Tag males than in females, this is most likely due to position effects of transgene insertion. The salivary glands of male mice may also be more susceptible than those of females to oncogene-induced tumor formation. Higher incidences of salivary gland hyperplasia and/or tumor development have also been observed in males of mouse lines containing the MMTV-activated retinoic acid receptor $\beta 4$ (Berard et al, 1994), MMTV-Neu (Muller et al, 1988) and MMTVRas (Sinn et al, 1987) transgenes.

Transgene-directed submandibular gland Tag expression has been reported previously. MMTVregulated Tag expression resulted in progressive ductal hyperplasia and dysplasia of striated duct (Choi et al, 1987; Ewald et al, 1996, Furth et al, 1998), whereas an EGF-Tag transgene caused hyperplasia and dysplasia that was restricted to granular convoluted tubules, the site of mouse submandibular gland EGF production (Pascall et al, 1994). Some MMTV-Tag mice observed over a 12-month period developed carcinoma of striated duct (Furth et al, 1998). Remarkably similar cytologic atypia and dysplastic duct organization occur in submandibular glands of these three transgenic models. These combined observations demonstrate that salivary gland dysplasias and tumors of similar morphology can arise from a variety of differentiated cell types. Additionally, these findings suggest that the nature of a molecular perturbation may dictate the resulting salivary gland histopathology. This is consistent with a previous survey of mammary tumor phenotypes in MMTV-Ras, MMTVMyc, and/or MMTV-Neu transgenic mice, where tumor morphology was closely correlated with the activated oncogene expressed (Cardiff et al, 1991). Accumulating cytogenetic and molecular biologic data indicate that specific human salivary tumors are often associated with predictable molecular perturbations (reviewed in Cerilli et al, 1999; El-Naggar et al, 1997; Johns et al, 1996; Sandros et al, 1990).

Limited information exists about the pathogenesis of salivary gland tumors. Ductal dysplasia and carcinoma in situ have been reported in association with squamous cell carcinoma of parotid (Leader and Jass, 

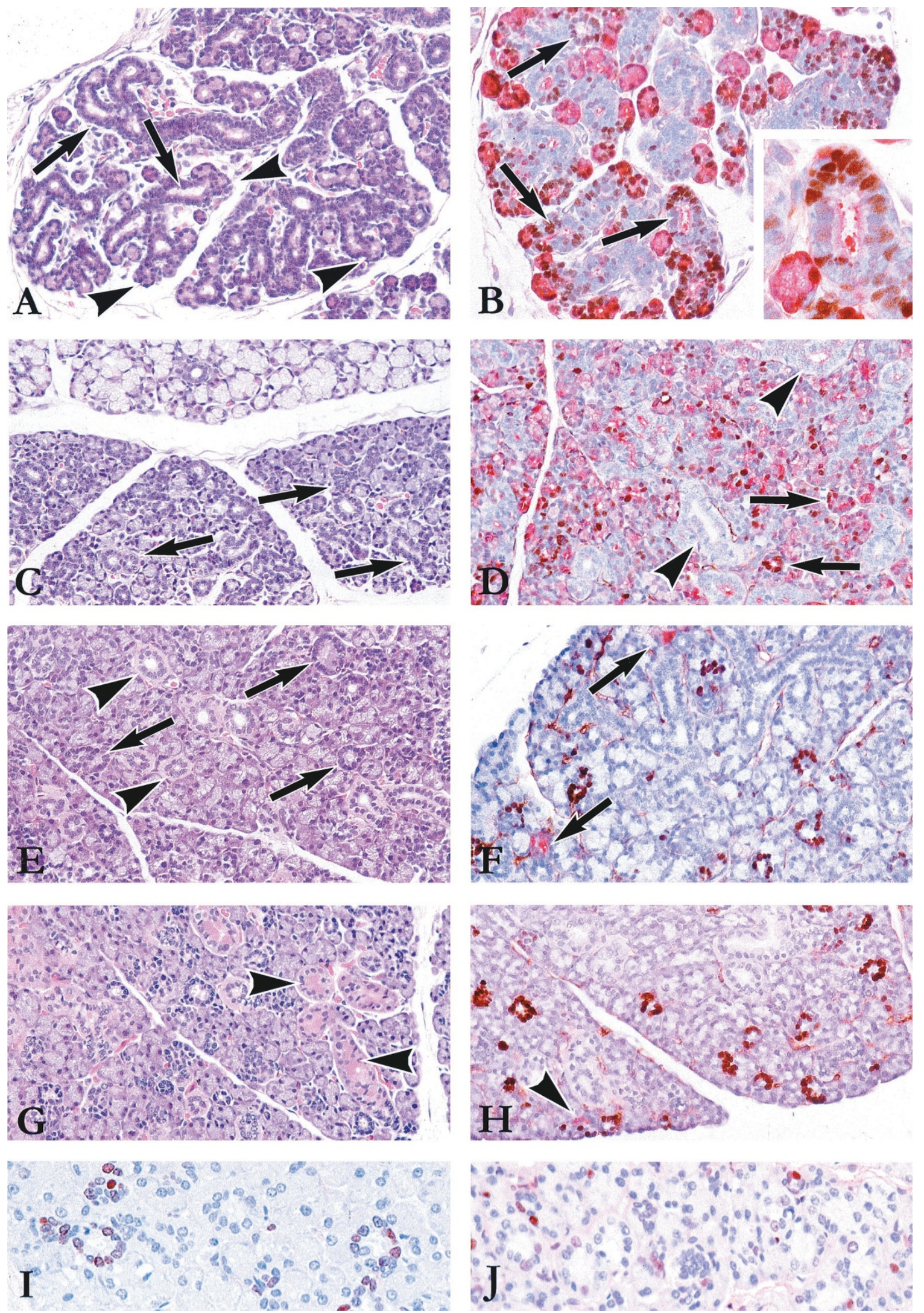

Figure 5 .

Histology and immunohistochemistry of submandibular glands of male Smgb-Tag mice at 3, 10, 20, and 30 days of age. Sections A, C, E, and G: H\&E, original magnification $\times 200$. Sections B, D, F and H: double immunoreactivity for PSP (red) and Tag (brown); original magnification, $\times 200$ (except $\times 400$ for inset on B). A, Immature lobules at 3 days of age have terminal tubules (arrows) with developing acini with proacinar and acinar cells at their tips (arrowheads). B, At 3 days of age, most PSP-immunoreactive proacinar and acinar cells are also immunoreactive for Tag, whereas the mainly PSP-negative terminal tubules (arrows) have a 

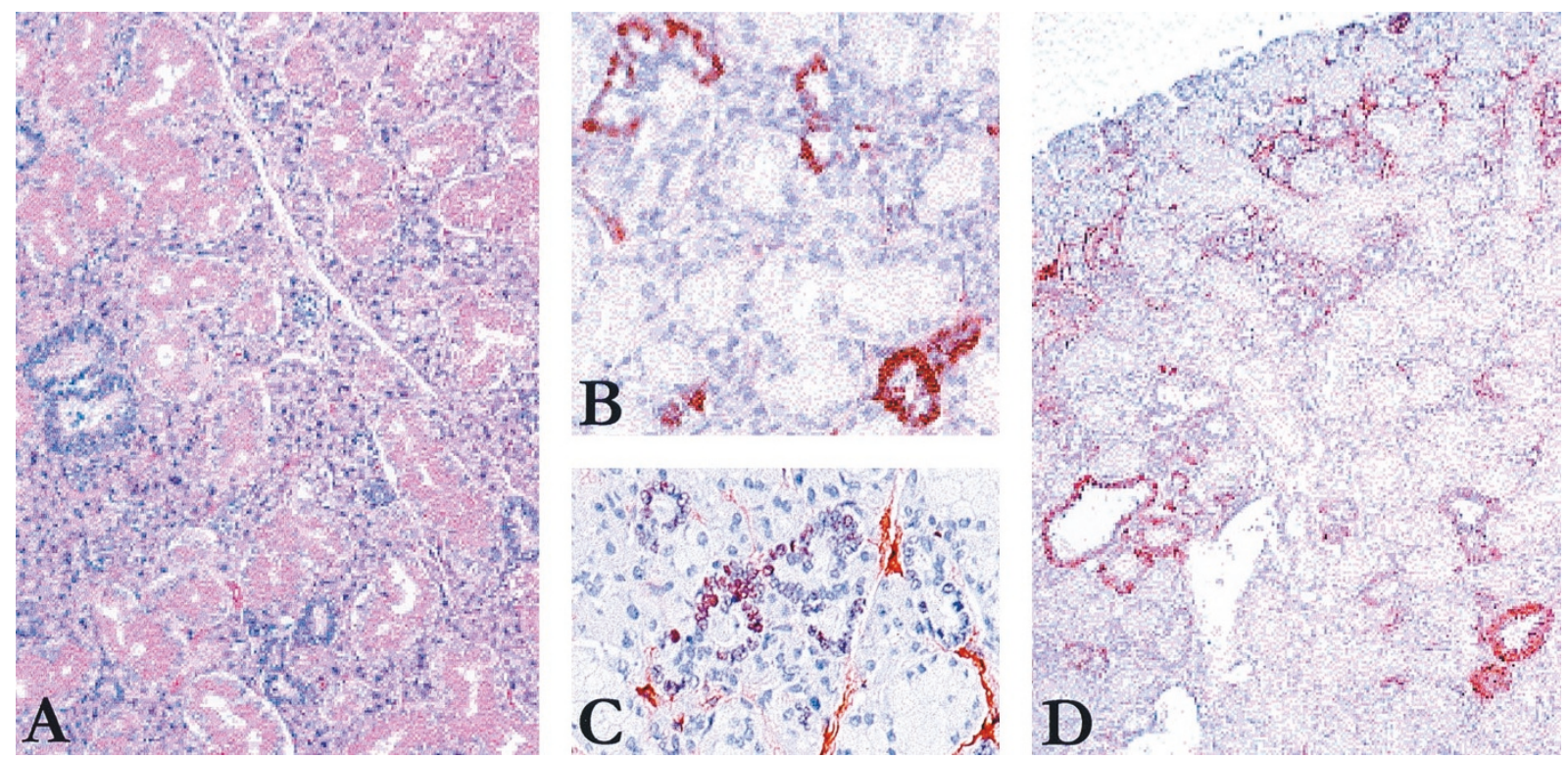

Figure 6.

Histology and immunohistochemistry of Smgb-Tag submandibular gland at 3 and 6 months of age. A, At 3 months, single and small groups of hyperplastic/dysplastic ducts are scattered among normal-appearing granular convoluted tubules and acini. H\&E; original magnification, $\times 125$. B, Expression of Tag is confined to hyperplastic/dysplastic ducts at 3 months of age. Pab 101 immunoreactivity; original magnification, $\times 200$. C, At 3 months of age, the majority of cycling cells also localize to abnormal ducts. PCNA immunoreactivity; original magnification, $\times 200$. D, At 6 months of age, Tag continues to be expressed in the clusters of abnormal ducts, now somewhat more prominent compared with submandibular gland at 3 months of age. Pab 101 immunoreactivity; original magnification, $\times 100$.

1985) and Wharton's duct (Dardick 1996b), but are more often a component of salivary duct carcinoma (Brandwein et al, 1990; Garland et al, 1984; Hui et al, 1986). In situ carcinoma is also part of the cytologic and histologic spectrum of carcinoma ex pleomorphic adenoma (Brandwein et al, 1996; LiVolsi and Perzin, 1977; Yamamoto et al, 1996, 1998). Hyperplasia of striated duct basal cells seems to be involved in the pathogenesis of some membranous basal cell adenomas (Yu et al, 1998). Premalignant changes, including degranulation and squamous metaplasia of granular convoluted ducts, precede the development of chemical carcinogen-induced carcinoma of the mouse submandibular gland (Takai et al, 1986). However, before the availability of transgenic mouse models there was no direct evidence implicating specific cell types in the genesis of salivary tumors. The Smgb-Tag, MMTVTag (Ewald et al, 1996; Furth et al, 1998), and EGF-Tag (Pascall et al, 1994) mice show that hyperplasia and premalignant changes can involve intercalated ducts, striated ducts, and granular convoluted tubules. Such information suggests that tumorigenesis can be lim- ited to specific, but differing, segments of the duct system of a particular salivary gland.

Can the adenocarcinoma developed in the submandibular gland of Smgb-Tag transgenic mice serve as a model for a human salivary gland tumor? Many human salivary gland tumors have distinct histologies and the adenocarcinoma in the Smgb-Tag transgenic mouse does not reflect one of these distinctive growth patterns. The histologic and ultrastructural evidence presented here indicates the central role of intercalated duct cells in the developmental phases leading to malignant tumors in Smgb-Tag submandibular glands. Furthermore, ultrastructural features of the adenocarcinoma closely resemble those of the luminal cells of normal and dysplastic intercalated ducts in these mice. Neoplastic intercalated duct cells often form a major component of human acinic cell carcinoma, sometimes to such an extent that there is only minimal evidence of acinar cell differentiation (Dardick, 1996a; Dardick et al, 1987; Ellis and Auclair, 1996). As a reflection of the human acinic cell carcinoma, in some adenocarcinomas in Smgb-Tag mice, occa-

high number of Tag-positive nuclei. Both features are detailed in inset. C, At 10 days of age, sections show developing intercalated and striated duct-like segments (arrows) among increasing numbers of acini. Normal-appearing sublingual gland at top of photo. D, At 10 days of age, PSP-immunoreactive proacinar and acinar cells continue to have Tag-immunoreactive nuclei and some intercalated ducts are also Tag-immunoreactive (arrows), but striated and excretory ducts segments are entirely negative (arrowheads). E, At 20 days of age, striated ducts (arrowheads) appear normal, but intercalated duct-like segments (arrows) appear somewhat enlarged with crowded nuclei. Acini are unremarkable. F, At 20 days of age, only a few acinar cells retain PSP (arrows) and the majority of these cells are negative for Tag. Tag expression is largely confined to intercalated ducts. G, At 30 days of age, normal-appearing granular convoluted tubules (arrowheads) are now present and hyperplastic/dysplastic intercalated ducts are more prominent, whereas the numerous acini continue to develop normally. $\mathrm{H}$, Only very occasional PSP-expressing acinar cells persist (arrowhead), and Tag expression seems entirely confined to intercalated ducts at 30 days of age. I, PCNA immunoreactivity of sections from Smgb-Tag mouse submandibular gland at 30 days of age show that in some hyperplastic ducts almost all of the luminal epithelial cells are cycling. Origina magnification, $\times 250$. J, No preferential localization occurs in the submandibular gland of a 30-day-old control mouse; the small number of cycling cells are evenly distributed between acinar cells and the cells of duct segments. Original magnification, $\times 200$. 

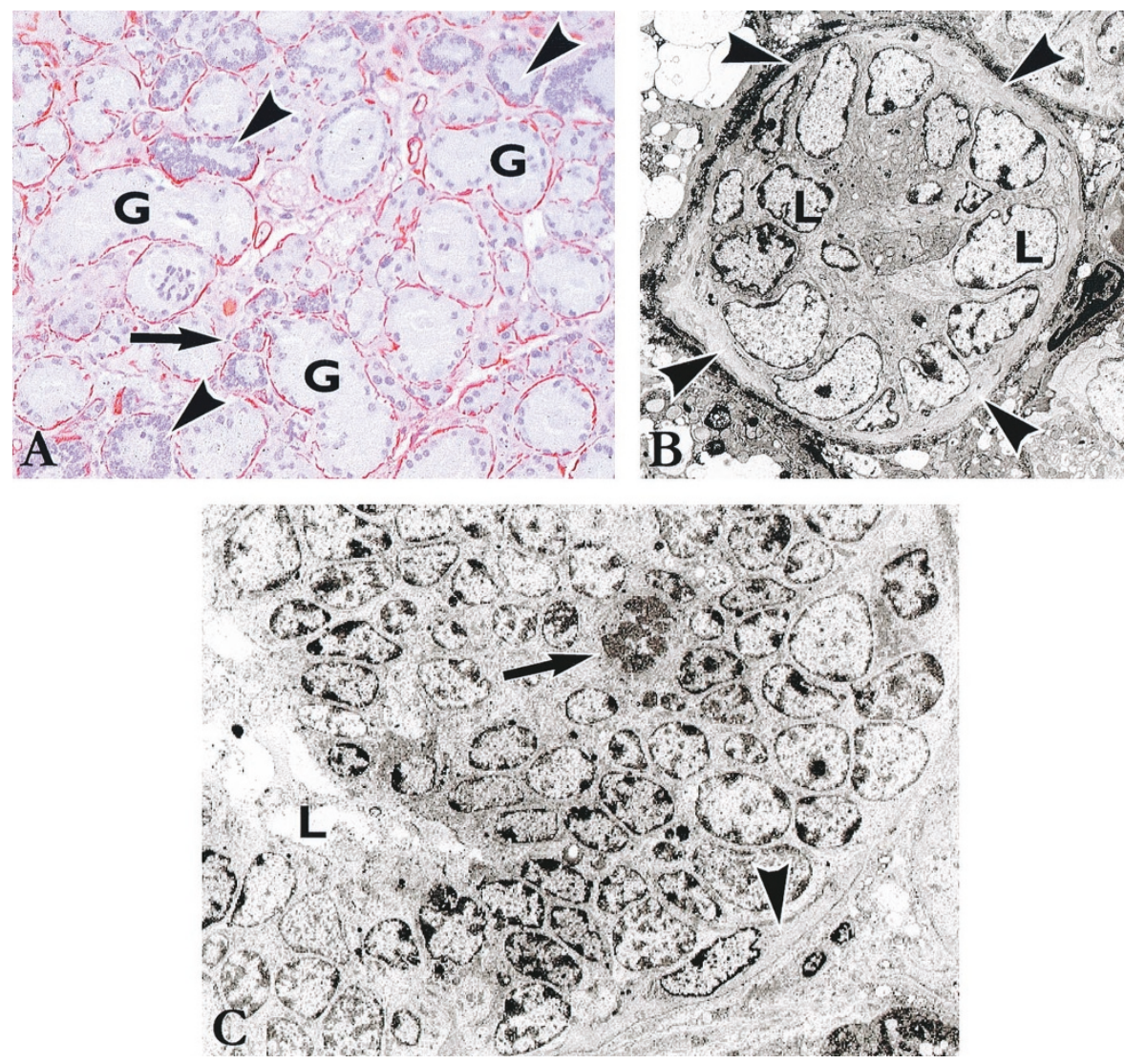

Figure 7.

Immunohistochemistry and ultrastructure of normal, hyperplastic, and dysplastic intercalated ducts in submandibular glands of male Smgb-Tag mice. A, Immunohistochemistry for muscle-specific actin, labeling myoepithelial cells, in submandibular gland of a male Smgb-Tag mouse without tumor at 13.5 months of age. Granular convoluted tubules $(G)$ and intercalated ducts have a rich complement of myoepithelial cells (arrow is at the junction between intercalated duct and granular convoluted tubule). Note the frequent association of myoepithelial cells with cross-sections of hyperplastic/dysplastic ducts (arrowheads). HHF35 immunoreactivity; original magnification, $\times 200$. B, Cross-section of a relatively normal-appearing intercalated duct with fairly uniform-appearing luminal cells $(L)$ almost entirely enclosed by myoepithelial cells (arrowheads). Uranyl acetate and lead citrate; original magnification, $\times 1650$. C, Dysplastic intercalated duct with advanced luminal cell proliferation (top and right) displacing the lumen $(L)$. Note the considerable nuclear variation in size and chromatin organization and mitotic figure (arrow). A normal-appearing myoepithelial cell continues to be evident at the periphery of the abnormal duct (arrowhead). Uranyl acetate and lead citrate; original magnification, $\times 1650$.

sional tumor cells contained secretory granules of the type seen in both normal and neoplastic human acinar cells. More typical acinar cells differentiate in MMTVRas transgenic mice with parotid gland adenocarcinoma having features similar to human acinic cell carcinoma (Dardick et al, 1992). However, in MMTVRas mouse adenocarcinoma, the cell of origin is unknown, and tumor formation is not accompanied by dysplasia or carcinoma in situ. Analysis of molecular alterations that accompany the development of progressive ductal dysplasia and adenocarcinoma in Smgb-Tag mice should help to elucidate the additional mechanisms contributing to salivary tumor formation.

\section{Materials and Methods}

\section{Construction of Transgene}

A Smgb/Tag transgene was prepared by ligation of putative Smgb regulatory regions from $-10.5 \mathrm{~kb}$ up- stream through $30 \mathrm{bp}$ downstream of the Smgb transcription start site to a $3.0 \mathrm{~kb}$ Xbal-Sall fragment encoding SV40 T and $t$ antigens. The Tag sequences, derived from RIP1-Tag (Hanahan, 1985), contain Tag translation initiation and transcription termination sequences, but no known promoter elements. The Xbal site of RIP1-Tag was changed to an Ascl site for cloning purposes by digestion with $\mathrm{Xbal}$, blunting with mung bean nuclease, and addition of Ascl linkers. An intermediate Smgb/Tag construct, Smgb1.1-Tag, was prepared from a $1.6 \mathrm{~kb}$ Pstl-EcoRl fragment of Smgb in pBluescript $\mathrm{KS}^{-}$. The Smgb fragment contained 1.1 $\mathrm{kb}$ of upstream sequence, the transcription start site and exon 1 (GenBank accession \#AF153355) plus 0.5 $\mathrm{kb}$ of Smgb intron 1. For insertion of Tag, nucleotides +23 to +30 of Smgb exon 1, GGCTTTCC, were mutagenized to an Ascl site, GGCGCGCC, using the Mut-a-Gene System (BioRad, Richmond, California). The final $20 \mathrm{bp}$ of Smgb exon 1 and the intronic sequences were removed by digestion with $\mathrm{Ascl}$ and 
Sall. Tag was then excised from RIP1-Tag by digestion with Ascl and Sall, and ligated to Smgb $1.1 /$ pBSKS $^{-}$.

The final Smgb/Tag plasmid, Smgb $\lambda 13$ Tag, was derived from Smgb genomic clone $\lambda 13$ (Gupta et al, 2000). Smgb $\lambda 13$, present in the Notl site of pBSKS $^{-}$in the same orientation as Smgb1.1-Tag, spans $10.5 \mathrm{~kb}$ upstream and $3.5 \mathrm{~kb}$ downstream of the Smgb transcription start site. Both $\lambda 13$ and Smgb1.1-Tag contain a unique BspEl site at -65 relative to the Smgb transcription start site. Smgb $\lambda 13 \mathrm{BSKS}^{-}$was digested with BspEl and Sall, and the $13.5 \mathrm{~kb}$ fragment containing the vector plus the Smgb upstream sequence was isolated by electroelution. This fragment was ligated to the corresponding $3 \mathrm{~kb}$ BspEl-Sall fragment from Smgb1.1-Tag (Smgb bp -65 to +30 plus Tag) to yield Smgb $\lambda 13$ Tag.

\section{Production of Transgenic Mice}

The $13.5 \mathrm{~kb}$ Smgb $\lambda 13-$ Tag transgene was excised by digestion with Notl and Sall and isolated by centrifugation through a $10 \%$ to $40 \%$ sucrose gradient in $1 \mathrm{~m}$ $\mathrm{NaCl}, 10 \mathrm{~mm}$ Tris- $\mathrm{HCl} \mathrm{pH} 8$, and $1 \mathrm{~mm}$ EDTA. Fractions containing the transgene were dialyzed against injection buffer (10 mm Tris HCl pH 7.4, 0.25 mm EDTA) and adjusted to a concentration of $2 \mu \mathrm{g} / \mathrm{ml}$. Isolated DNA was used to inject pronuclei of fertilized one-cell embryos derived from the mating of $\mathrm{CB} 6 \mathrm{~F} 1 / \mathrm{J}$ mice (C57BI/6J x BALB/cJ; Harlan Sprague Dawley, Indianapolis, Indiana). Injected embryos were implanted into pseudopregnant CD-1 hosts. Transgenic mice were identified by Southern blotting of DNA prepared from tail samples.

\section{Harvesting of Organs and Fixation}

The Public Health Service Policy on Humane Care and Use of Laboratory Animals was followed throughout this project. In time course studies, the day of birth was defined as day 0 . For preparation of RNA, submandibular, sublingual, and parotid glands of 3-month-old heterozygous mice, and submandibular/ sublingual complexes from 2- to 4-day-old neonatal mice were dissected and frozen in liquid nitrogen. To insure an adequate yield from neonatal samples, heterozygous adults from each line were mated, and glands from all transgenic offspring of a single mating pooled for RNA preparation. For morphologic analysis by light microscopy, duplicate samples were taken from each salivary gland and tumor. Duplicate samples were fixed overnight at $4^{\circ} \mathrm{C}$, one in $10 \%$ neutral buffered formalin and the other in methacarn $(10 \%$ acetic acid, 90\% methanol) and then infiltrated with and embedded in paraffin. Electron microscopic samples were fixed in $2 \%$ paraformaldehyde, $2.5 \%$ glutaraldehyde in $0.1 \mathrm{M}$ sodium phosphate, $\mathrm{pH} 7.4$, and embedded in Epon.

\section{Reverse Transcriptase PCR}

RNA was prepared by the method of Chomczynski and Sacchi (1987). Two micrograms of total RNA were denatured at $90^{\circ} \mathrm{C}$ for 5 minutes in the presence of $175 \mathrm{ng}$ of random hexamers. The sample was brought to $50 \mathrm{mM}$ Tris HCL, $0.5 \mathrm{~mm}$ each of dGTP, dATP, dCTP, and dTTP, $20 \mathrm{U}$ of RNAsin (Promega, Madison, Wisconsin) and $200 \mathrm{U}$ of MMuLV reverse transcriptase (Boehringer Mannheim, Indianapolis, Indiana) in a final volume of $20 \mu \mathrm{l}$ and incubated at $37^{\circ} \mathrm{C}$ for 1 hour. One microliter of the reverse transcriptase reaction was diluted 1:100 in $50 \mathrm{~mm} \mathrm{KCl}, 2.5 \mathrm{~mm} \mathrm{MgCl}_{2}, 0.2 \mathrm{~mm}$ each of dNTP, $2.5 \times 10^{-6} \mathrm{M}$ Tag forward and reverse primers, and $5 \mathrm{U}$ of Taq polymerase (Boehringer Mannheim), and incubated at $94^{\circ} \mathrm{C}$ for 1 minute, and $35^{\circ} \mathrm{C}$ for 1 minute for 30 cycles. Tag primers were forward: 5' TAGGTCTTGAAAGG (reverse and complement of Tag bp 5097 to 5114) and reverse: 5' CTCATCATCACTAGATGG (Tag bp 4473 to 4490; GenBank accession \#J02400). These primers flank a 346 bp intron in the Tag gene, such that fragments amplified from Tag transcripts are $296 \mathrm{bp}$ whereas those derived from contaminating genomic DNA are $642 \mathrm{bp}$. Reaction products were separated by electrophoresis through $1.5 \%$ agarose gels, transferred to Gene Screen and detected by hybridization to a ${ }^{32} \mathrm{P}$ labeled Tag probe. Positive control RNA was derived from the Tag-producing cell line alpha T3-1 (Alarid et al, 1996).

\section{Immunohistochemistry}

The monoclonal SV40 T antigen antibody, Pab 101, was obtained from Santa Cruz Biotechnology (Santa Cruz, California). The monoclonal muscle-specific actin antibody, HHF35, was kindly supplied by Dr. A. M. Gown, University of Washington, Seattle, Washington. The monoclonal PCNA antibody, PC10, was obtained from NovoCastra Laboratories (Newcastle upon Tyne, United Kingdom). The polyclonal rabbit PSP antiserum (anti-M1; Ball et al, 1993) was kindly supplied by Dr. W. D. Ball, Howard University, Washington, DC. Paraffin sections of $3 \mu \mathrm{m}$ thickness were cut onto silanized slides. After dewaxing and rehydration, the slides were treated in 3\% hydrogen peroxide to block endogenous peroxidase activity. For Pab101 antibody studies, formalin-fixed sections were treated in $0.4 \%$ pepsin ( $\mathrm{pH}$ 2.0). Pretreatment of methacarn-fixed sections for other antibodies was not necessary. The following procedures were carried out at room temperature.

Sections were incubated with monoclonal antibodies overnight at the following dilutions: Pab 101, 1:500; HHF35, 1:50; PC10, 1:100; or with anti-M1 at a 1:8000 dilution for 1 hour. After primary antibody application, slides were washed in PBS and, in the cases of Pab101, HHF35, and PC10, a secondary system was applied using the Vector elite ABC mouse kit (Vector Laboratories, Inc., Burlingame, California). For the PSP antibody, the secondary system used biotinconjugated anti-rabbit IgG (Vector Laboratories, Inc.) followed by streptavidin-horseradish peroxidase (USA Ultrastreptavidin system, Signet Pathology Systems, Inc., Dedham, Massachusetts). In all cases, the resulting immunoreaction was revealed by incubation in 3-amino-9-ethyl-carbazole in acetate buffer ( $\mathrm{pH} 5.2$ ). 
Slides were counterstained in Mayer's hematoxylin and mounted with Crystal Mount (Biomeda Corporation, Foster City, California). Dual immunohistochemistry with Pab101 and anti-PSP was performed using a variation of the above techniques. The Pab101 and secondary complex was labeled with 3-3'diaminobenzidine tetrahydrochloride and anti-PSP was labeled with New Fuchsin after incubation with streptavidin conjugated to alkaline phosphatase instead of horseradish peroxidase.

\section{Acknowledgements}

The authors appreciate the invaluable technical assistance of Abigail Miranda and Neil Gupta (with maintenance and analysis of transgenic mice), of Nusi Dekker (with preparation of samples for light microscopy), and of Bob Munn and Richard Leung (with fixation and embedding of electron microscopic samples). We thank Mark Lawson for advice on preparation of the Smgb-Tag transgene for injection, and on analysis of Tag expression, and Priscilla Furth for advice on Tag immunohistochemistry. Thanks also to Bruce Patterson and Art Hand for helpful discussions. These data were presented in part at the American Academy of Oral and Maxillofacial Pathology annual meeting, Kohala Coast, Hawaii, June 7, 1999.

\section{References}

Alarid EA, Windle JJ, Whyte DB, and Mellon PL (1996). Immortalization of pituitary cells at discrete stages of development by directed oncogenesis in transgenic mice. Development 122:3319-3329.

Ball WD, Hand AR, and Johnson AO (1988). Secretory proteins as markers for cellular phenotypes in rat salivary glands. Dev Biol 125:265-279.

Ball WD, Hand AR, Moreira JE, Iversen JM, and Robinovitch MR (1993). The B1-immunoreactive proteins of the perinatal submandibular gland: Similarity to the major parotid gland protein, RPSP. Crit Rev Oral Biol Med 4:517-524.

Belsky JL, Takeichi N, Yamamoto T, Cihak RW, Hirose F, Ezaki H, Inoue S, and Blot WJ (1975). Salivary gland neoplasms following atomic radiation: Additional cases and reanalysis of combined data in a fixed population, 19571970. Cancer 35:555-559.

Berard J, Gaboury L, Landers M, DeRepentigny Y, Houle B, Kothary R, and Bradley WEC (1994). Hyperplasia and tumours in lung, breast and other tissues in mice carrying a RAR $\beta 4$-like transgene. EMBO J 13:5570-5580.

Borg MF, Benjamin CS, Morton RP, and Llewellyn HR (1993). Malignant lympho-epithelial lesion of the salivary gland: A case report and review of the literature. Australas Radiol 37:288-291.

Brandwein M, Huvos AG, Dardick I, Thomas MJ, and Thiese ND (1996). Noninvasive and minimally invasive carcinoma ex mixed tumor: A clinicopathologic and ploidy study of 12 patients with major salivary tumors of low (or no?) malignant potential. Oral Surg Oral Med Oral Pathol Oral Radiol Endod 81:665-664.
Brandwein MS, Jagirdar J, Patil J, Biller $\mathrm{H}$, and Kaneko M (1990). Salivary duct carcinoma (cribriform salivary carcinoma of excretory ducts): A clinicopathologic and immunohistochemical study of 12 cases. Cancer 65:2307-2314.

Breuer M (1991). The use of transgenic mice in unraveling the multistep process of tumorigenesis. Radiat Envirn Biophys 30:181-183.

Cardiff RD, Sinn E, Muller W, and Leder P (1991). Transgenic oncogene mice. Tumor phenotype predicts genotype. Am J Pathol 139:495-501.

Cerilli LA, Swartzbaugh JR, Saadut R, Marshall CE, Rumpel CA, Moskaluk CA, and Frierson HF Jr (1999). Analysis of chromosome 9p21 deletion and p16 gene mutation in salivary gland carcinomas. Hum Pathol 30:1242-1246.

Choi Y, Henrad D, Lee I, and Ross SR (1987). The mouse mammary tumor virus long terminal repeat directs expression in epithelial and lymphoid cells of different tissues in transgenic mice. J Virol 61:3013-3019.

Chomczynski P and Sacchi N (1987). Single-step method of RNA isolation by acid guanidinium thiocyanate-phenolchloroform extraction. Anal Biochem162:156-159.

Daphna-Iken D, Shankar DB, Lawshé A, Ornitz DM, Shackleford GM, and MacArthur CA (1998). MMTV-Fgf8 transgenic mice develop mammary and salivary gland neoplasia and ovarian stromal hyperplasia. Oncogene 17:2711-2717.

Dardick I (1996a). Acinic cell carcinoma. In: Color Atlas/Text of Salivary Gland Tumor Pathology. New York: Igaku-Shoin, 199-209.

Dardick I (1996b). Morphogenesis and pathogenesis. In: Color Atlas/Text of Salivary Gland Tumor Pathology. New York: Igaku-Shoin, 25-26.

Dardick I, Burford-Mason AP, Garlick DS, and Carney WP (1992). The pathobiology of salivary gland. II. Morphological evaluation of acinic cell carcinomas in the parotid gland of male transgenic (MMTV/v-Ha-ras) mice as a model for human tumours. Virchows Archiv A Pathol Anat 421:105-113.

Dardick I, George D, Jeans MTD, Wittkuhn JF, Skimming L, and van Nostrand AWP (1987). Ultrastructural morphology and cellular differentiation in acinic cell carcinoma. Oral Surg Oral Med Oral Pathol 63:325-334.

Dawe CJ (1979). Tumors of the salivary and lacrymal glands, nasal fossa, and maxillary sinuses. In: Turusov VS, ed. Pathology of Tumors in Laboratory Animals. Vol II. Tumours of the mouse. Lyon: International Agency for Research in Cancer Publications, 91-133.

Eddy BE (1969). Polyoma virus. Virol Monogr 7:1-114.

Ellis GL and Auclair PL (1996). Acinic cell adenocarcinoma. In: Altas of Tumor Pathology; Tumors of the Salivary Glands. Washington, DC; Armed Forces Institute of Pathology, 183203.

El-Naggar AK, Hurr K, Kagan J, Gillenwater A, Callender D, Luna MA, and Batsakis JG (1997). Genotypic alterations in benign and malignant salivary gland tumors: Histogenetic and clinical implications. Am J Surg Pathol 21:691-697.

Ewald D, Li M, Efrat S, Auer G, Wall RJ, Furth PA, and Hennighausen $L$ (1996). Time-sensitive reversal of hyperplasia in transgenic mice expressing SV40 T antigen. Science 273:1384-1386. 
Furth PA, Li M, and Hennighausen L (1998). Studying development of disease through temporally controlled gene expression in the salivary gland. Ann N Y Acad Sci 842:181187.

Garland TA, Innes DJ Jr, and Fechner RE (1984). Salivary duct carcinoma: An analysis of four cases with review of the literature. Am J Clin Pathol 81:436-441.

Gresik EW and MacRae EK (1975). The postnatal development of the sexually dimorphic duct system and of amylase activity in the submandibular glands of mice. Cell Tissue Res 157:411-422.

Gupta N, Asp E, Levan G, and Mirels L (2000). Structure and chromosomal localization of the rat salivary Psp and Smgb genes. Gene 243:11-18.

Hamilton-Dutoit SJ, Therkildsen $\mathrm{MH}$, Neilsen $\mathrm{NH}$, Jensen $\mathrm{H}$, Hanson JPH, and Pallesen G (1991). Undifferentiated carcinoma of the salivary gland in Greenlandic Eskimos: Demonstration of Epstein-Barr virus DNA by in situ nucleic acid hybridization. Hum Pathol 22:811-815.

Hanahan D (1985). Heritable information of pancreatic beta cell tumors in transgenic mice expressing recombinant insulin/simian virus 40 oncogenes. Nature 315:115-122.

Hecht R, Connelly M, Marchetti L, Ball WD, and Hand AR (2000). Cell death during development of intercalated ducts in the rat submandibular gland. Anat Rec 258:349-358.

Hui KK, Batsakis JG, Luna MA, Mackay B, and Byers RM (1986). Salivary duct adenocarcinoma: A high grade malignancy. J Laryngol Otol 100:105-114.

Jhappan C, Gallahan D, Stahle C, Chu E, Smith GH, Merlino G, and Callahan R (1992). Expression of an activated notchrelated int-3 transgene interferes with cell differentiation and induces neoplastic transformation in mammary and salivary glands. Genes Dev 6:345-355.

Johns MM 3rd, Westra WH, Califano JA, Eisele D, Koch WM, and Sidransky D (1996). Allelotype of salivary gland tumors. Cancer Research 56:1151-1154.

Kuo T and Hsueh C (1997). Lymphoepithelioma-like salivary gland carcinoma in Taiwan: A clinicopathological study of nine cases demonstrating a strong association with EpsteinBarr virus. Histopathology 31:75-82.

Leader M and Jass JR (1985). In-situ neoplasia in squamous cell carcinoma of the parotid: A case report. Histopathology 9:325-329.

LiVolsi VA and Perzin KH (1977). Malignant mixed tumors arising in salivary glands. I. Carcinomas arising in benign mixed tumors: A clinicopathologic study. Cancer 39:22092230.

Lucchini F, Sacco MG, Hu N, Villa A, Brown J, Cesano L, Mangiarini L, Rindi G, Kindl S, Sessa F, Vezzoni P, and Clerici $L$ (1992). Early and multifocal tumors in breast, salivary, Harderian and epididymal tissues developed in MMTV-Neu transgenic mice. Cancer Letters 64:203-209.

Maxon HR, Saenger EL, Buncher CR, Thomas SR, Kereiakes JG, Shafer ML, and McLaughlin CA (1981). Radiationassociated carcinoma of the salivary glands: A controlled study. Ann Otolaryngol 90:107-108.

Mirels L, Miranda AJ, and Ball WD (1998). Characterization of the rat salivary gland $\mathrm{B} 1$-immunoreactive proteins. Biochem J 330:437-444.
Modan B, Baidatz D, Mart H, Steinitz R, and Levin SG (1974). Radiation-induced head and neck tumors. Lancet 1:277-279.

Moreira JE, Hand AR, and Ball WD (1990). Localization of neonatal secretory proteins in different cell types of the rat submandibular gland from embryogenesis to adulthood. Dev Biol 139:370-382.

Muller WJ, Sinn E, Pattengale PK, Wallace R, and Leder P (1988). Single-step induction of mammary adenocarcinoma in transgenic mice bearing the activated c-neu oncogene. Cell 54:105-115.

Nagao T, Ishida Y, Sugano I, Tajima Y, Matsuzaki O, Hino T, Konno A, Kondo Y, and Nagao K (1996). Epstein-Barr virusassociated undifferentiated carcinoma with lymphoid stroma of the salivary glands in Japanese patients: Comparison with benign lymphoepithelial lesion. Cancer 78:695-703.

Palmer JA, Mustard RA, and Simpson WJ (1980). Irradiation as an etiologic factor in tumors of the thyroid, parathyroid, and salivary glands. Can J Surg 23:39-42.

Pascall JC, Surani MA, Barton SC, Vaughan TJ, and Brown KD (1994). Directed expression of simian virus 40 T-antigen in transgenic mice using the epidermal growth factor gene promoter. J Mol Endocrinol 12:313-325.

Sandros J, Stenman G, and Mark J (1990). Cytogenetic and molecular observations in human and experimental salivary gland tumors. Cancer Genet Cytogenet 44:153-167.

Schaffner DL, Barrios R, Shaker MR, Rajagopalan S, Huang SL, Tindall DJ, Young CYF, Overbeek PA, Lebovitz RM, and Lieberman MW (1995). Transgenic mice carrying a PASrasT24 hybrid gene develop salivary gland and gastrointestinal tract neoplasms. Lab Invest 72:283-290.

Sheen TS, Tsai CC, Ko JY, Chang YL, and Hsu MM (1997). Undifferentiated carcinoma of the major salivary glands. Cancer 80:357-363.

Sinn E, Muller W, Pattengale P, Tepler I, Wallace R, and Leder P (1987). Coexpression of MMTV/v-Ha-ras and MMTV/c-myc genes in transgenic mice: Synergistic action of oncogenes in vivo. Cell 49:465-475.

Spitz MR, Tilley BC, Batsakis JG, Gibeau JM, and Newell GR (1984). Risk factors for major salivary gland carcinoma: A case-comparison study. Cancer 54:1854-1859.

Srinivasan R and Chang WWL (1979). The postnatal development of the submandibular gland of the mouse. Cell Tissue Res 198:363-371.

Takai Y, Murase N, Hosaka M, Kawamura K, and Mori M (1986). Immunohistochemical localization of keratin in experimental carcinoma of the mouse submandibular gland. J Oral Pathol 15:5-10.

Tsukamoto AS, Grosschedl R, Guzman RC, Parslow T, and Varmus HE (1988). Expression of the int-1 gene in transgenic mice is associated with mammary gland hyperplasia and adenocarcinomas in male and female mice. Cell 55:619-625.

Wen S, Mizugaki Y, Shinozaki F, and Takada K (1997). Epstein-Barr virus (EBV) infection in salivary gland tumors: Lytic EBV infection in nonmalignant epithelial cells surrounded by EBV-positive T-lymphoma cells. Virology 227: 484-487.

Yamamoto Y, Kishimoto Y, Virmani AK, Smith A, Vuitch F, Albores-Saavedra J, and Gazdar AF (1996). Mutations associated with carcinomas arising from pleomorphic adenomas of the salivary glands. Hum Pathol 27:782-786. 
Yamamoto Y, Kishimoto Y, Wistuba II, Virmani AK, Vuitch F, Gazdar AF, and Albores-Saavedra J (1998). DNA analysis at p53 locus in carcinomas arising from pleomorphic adenomas of salivary glands: Comparison of molecular study and p53 immunostaining. Pathol Int 48:265-272.
Yu G-Y, Ussmueller J, and Donath K (1998). Histogenesis and development of membranous basal cell adenoma. Ora Surg Oral Med Oral Pathol Oral Radiol Endod 86:446-451. 